\title{
Instruments for analysing skills shortages
}

Citation for published version (APA):

Hoevenberg, J., van de Loo, P., \& van der Velden, R. K. W. (1994). Instruments for analysing skills shortages. Researchcentrum voor Onderwijs en Arbeidsmarkt, Faculteit der Economische Wetenschappen. ROA Working Papers No. 5E https://doi.org/10.26481/umarow.199405E

Document status and date:

Published: 01/01/1994

DOI:

10.26481/umarow.199405E

Document Version:

Publisher's PDF, also known as Version of record

\section{Please check the document version of this publication:}

- A submitted manuscript is the version of the article upon submission and before peer-review. There can be important differences between the submitted version and the official published version of record.

People interested in the research are advised to contact the author for the final version of the publication, or visit the DOI to the publisher's website.

- The final author version and the galley proof are versions of the publication after peer review.

- The final published version features the final layout of the paper including the volume, issue and page numbers.

Link to publication

\footnotetext{
General rights rights.

- You may freely distribute the URL identifying the publication in the public portal. please follow below link for the End User Agreement:

www.umlib.nl/taverne-license

Take down policy

If you believe that this document breaches copyright please contact us at:

repository@maastrichtuniversity.nl

providing details and we will investigate your claim.
}

Copyright and moral rights for the publications made accessible in the public portal are retained by the authors and/or other copyright owners and it is a condition of accessing publications that users recognise and abide by the legal requirements associated with these

- Users may download and print one copy of any publication from the public portal for the purpose of private study or research.

- You may not further distribute the material or use it for any profit-making activity or commercial gain

If the publication is distributed under the terms of Article $25 \mathrm{fa}$ of the Dutch Copyright Act, indicated by the "Taverne" license above, 


\section{Instruments for Analysing Skills Shortages}

J. Hoevenberg, P.J.E. van de Loo, R.K.W. van der Velden

ROA-W-1994/5E

Report on the first phase of the project 'Transnational cooperation between regional networks for analysing skills needs'

This project was financially supported by the European Commission, Task Force Human Resources, Education, Training and Youth

Research Centre for Education and the Labour Market

Faculty of Economics and Business Administration

University of Limburg

Maastricht, September 1994 
Hoevenberg, J.

Instruments for Analysing Skills Shortages / J. Hoevenberg, P.J.E. van de Loo, R.K.W. van der Velden. Maastricht : Research Centre for Education and the Labour Market, Faculty of Economics and Business Administration, University of Limburg. - ([Working Paper] / Research Centre for Education and the Labour Market, ISSN 0922-4645; ROA-W-1994/5E)

Report on the first phase of the project 'Transnational cooperation between regional networks for analysing skills needs.'

ISBN 90-5321-139-X

Trefw.: werkgelegenheid ; Europa. 


\section{Contents}

Page

1 Introduction 1

2 Transmit 5

3 Mantel project 11

4 Curriculum conference 15

5 Information system on education and the labour market 21

6 Labour market scanners 25 



\section{Introduction}

In October 1993, the Task Force Human Resources, Education, Training and Youth launched a project involving the transnational cooperation between regional networks for analysing skills needs.

The objectives are:

- to capitalise on achievements and results of the regional Skills Network and its various activities;

- to reinforce transnational cooperation between the driving actors in regions concerned with vocational training;

- to reinforce cooperation on methodologies for analysing skills needs and subsequently, methods and practices in view of the transfer of examples of good practice contributing to regional development;

- to extend the practices of actors being involved in EC education and training programmes at regional level, and thus prepare all actors concerned to participate in the Regional Operational Centres, proposed within the context of the envisaged vocational training programme.

Regions involved in earlier phases of the so-called Skills Shortages Project ${ }^{1}$ were asked to form a regional network which involved relevant actors in the field of education and labour market. In Limburg the project was carried out by ROA together with RDC-Limburg.

As of 1993, RDC-Limburg organises the so-called Platform for Education and Labour Market in North and Middle Limburg, in which representatives participate from:

- the local councils;

- the Regional Employment Board;

- the Chambers of Commerce;

- employer's organisations;

- trade unions;

- institutes of education.

This Platfom therefore serves as the above mentioned regional network and also contributes financially to the project.

In the first phase of the project ROA and RDC-Limburg have investigated the instruments which are used for analysing skills shortages. RDC-Limburg has concentrated on the instruments that are used by labour organisations in the region of North and Middle Limburg. The results of their survey are published separately ${ }^{2}$.

This report contains the results of ROA's investigation after national and sectoral instruments for analysing skills shortages. The aim was to find examples of best practice, which can be used by other regions participating in the project. This meant that the selection focussed on instruments which are currently used on a more regular basis, which have proved themselves in practice and which can in principle be transferred to other regions.

1. See TARGET (1991), EC Skills Shortages Project 1990/1991. Final Synthesis Report. See also T. Casey (1992), Supply/Demand Interfaces in Education \& Training in the Regions of the European Community, Dublin.

2. See Beterams, H and R. El-Namaki (1994), Skills Needs Analyses, Geleen: RDC Limburg. 
These criteria resulted in the selection of five different instruments:

1. Transmit developed by A\&O, Bunnik;

2. Mantel project developed by PCBB, 's-Hertogenbosch;

3. Curriculum conference developed by the University of Twente, Enschede;

4. Information System on Education and the Labour Market developed by ROA, Maastricht;

5. Labour market scanners developed by ROA, Maastricht.

Scheme 1 gives an overview of the main characteristics of these five instruments. They are described in more detail in the following chapters.

Scheme 1

Description of selected instruments

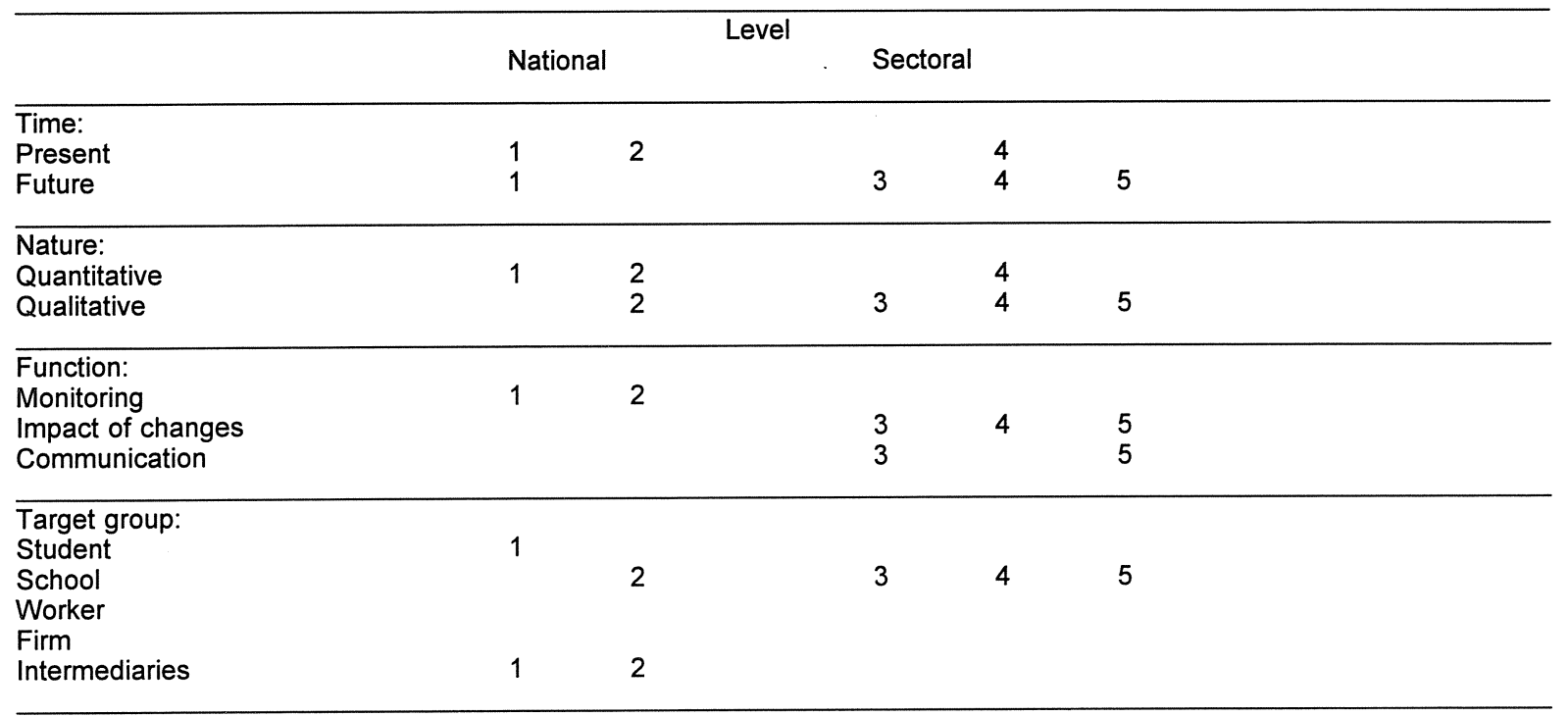

Legenda:

1. Information System on Education and the Labour Market

2. Labour market scanners

3. Transmit

4. Mantel project

5. Curricculum conference

As can be seen from scheme 1, both ROA instruments are designed for national purposes, the other three are sectoral instruments.

There are differences with respect to the time period on which the instruments focus. All instruments, with exception of the labour market scanners, focus on future skills shortages. However, the Information System and the Mantel project also present information about the present skills shortages.

The instruments also differ in the nature of the skills shortages on which they focus. The Information System e.g. focusses entirely on quantitative skills shortages. Transmit and Curriculum Conference on the other hand highlight the qualitative skills shortages. The other two instruments take both kinds of skills shortages into account.

One of the principal functions of the ROA instruments is to monitor present and future developments on the labour market. The sectoral instruments are primarily aimed at investigating the effects of (technological) changes on the skills needs. Moreover, Transmit and Currriculum Conference also serve a function of facilitating communication between supply and demand side of the labour market. 
All five instruments give information about skills shortages. Possible target groups for this information involve students, institutes of education and training, workers, firms and intermediary organisations. There is only one instrument which aims to give information to students, in order to prevent future skills shortages: the Information System. The principal target group for the other instruments are the institutes of education and training. None of the instruments was specifically aimed at giving information about the skills shortages to workers or firms. Finally, the intermediary organisations are also an important target group for the ROA instruments. 



\section{Transmit}

Introduction

Involvement

Aim

Sectoral

Design

Branch study

Innovations

Skills profile

Information

Translation steps
In the fall of 1991 the central organizations of employers, the trade unions and the government signed the convenant "Working together at the vocational education". One of the issues of the convenant is concerned about a clear answer on the question what specific training and educational needs the employers experience for their (potential) employees.

The Ministry of Economic Affairs therefore commissioned the project TRANSMIT to A\&O (Centre for Education Training and Work) in Bunnik, the Netherlands.

The aim of TRANSMIT is to develop tools and instruments to stimulate the communication about the demand and supply of training between branches of industry and suppliers of training. With these instruments the branches of industry are supposed to be able to formulate clear and specific educational needs. The practical usefulness of the TRANSMIT instruments and results for the staff of branch organizations and training institutes was one of the most important conditions at the development of TRANSMIT.

TRANSMIT is in the first place designed as a sectoral instrument. A central (or regional) organization of employers of a certain branch of industry takes the initiative to start the TRANSMIT process. Most of the activities will be executed by this organization and by employers and employees of this branch of industry. At certain parts of the TRANSMIT process representatives of the relevant training institutes come into action. At the end of the TRANSMIT process both sides work together to respond to the observed mismatch between required and offered skills. During the process consultants or researchers can be called in.

The starting point of TRANSMIT is the study of the chosen branch of industry. This study encloses (statistical) data about the history, economic developments and personnel categories of the branch of industry. Furthermore the study contains information about the - for this branch of industry - relevant educational and organizational infrastructure. The (statistical) information can partly be derived from already existing statistics and literature.

TRANSMIT gives special attention to the effects of (branch specific) innovations to the (changing) contents of jobs and occupations. These innovations concern government regulation, changes in market conditions, and technological and organizational developments. The branch study is therefore focused on developments and demands in the (immediate) future.

Next to it the supply of - for these occupations - relevant types of training are analysed. By matching the required skills profile and the offered training profile one can identify the socalled 'white' and 'black' spots of the type(s) of training. White spots are the result of the fact that the type of training gives too little attention to required skills. On the contrary, black spots arise when the type of training gives too much attention to this skills.

On base of this match a plan of action can be arranged.

It is clear that the results of the branch study can't directly be used to draw conclusions for changes in the course of training. The information from the 
domain of the branch of industry must be translated into the educational domain. When the experts of both sides consult each other about the required and offered skills, it is important that they speak the same 'language'. Translation steps are therefore necessary. In scheme 1 these steps of TRANSMIT are summarized.

\section{Methods}

Delivery time

Costs

Development

Validity and
This scheme also shows the kinds of instruments which are used during the TRANSMIT process. In TRANSMIT most information is collected by interviews and questionnaires with a relative small group of experts of the branche of industry and of the selected type(s) of training. Large-scale surveys are avoided. During the process the instruments used are more and more focused on the generation of (highly) structured information.

The TRANSMIT process can be run on in a relative short time. TRANSMIT claims that the activities can be completed within 12 weeks. However, it is important that the responsibility for the process is held in one hand.

The execution of TRANSMIT has relative low costs. If the research and accompanying activities are executed by a branch organization, some 30 experts are involved who participate free of charge, and the panel conference is planned soberly, the costs are some 50,000 Dutch guilders (ca. 25,000 ECU). The costs for following actions are not included (step 6 in scheme 1).

The project TRANSMIT has started with a preliminary study in 56 branches of industry to investigate the attention these industrial branches give to their educational needs. On the base of this preliminary study and comprehensive interviews with representitives of the branches of industry, six different branches were selected to participate actively in the developing process of the TRANSMIT method. The pilot-study has also resulted in the development of the 'innovation filter': for all of the observed innovations can be indicated whether this innovation has consequences for the tasks in a certain job and if so, what the consequences are for the required skills (see also scheme 1). Furthermore TRANSMIT developed a practical applicable instrument and procedure to translate the study of the branch of industry to concrete demands for training and schooling. This communication-instrument is a highly structured questionnaire, whereby experts of the branche of industry indicate whether a certain skill is not important, less important, important or very important for a good pursuance of the profession. These experts also can mention other skills which they consider important to practise the investigated job or occupation correctly. Besides for all of these (appended) skills the experts indicate whether a certain skill is nowadays a bottleneck in the occupational practice or not. The experts of the corresponding type(s) of training fill in the same questionnaire for the offered skills. But the level of importancy refers now to the extent of attention the type of training gives to a certain skill. The differences in the results of this questionnaire between the experts of the branch of industry and of the type of training, the 'white and black spots', are discussed at a panel conference for them.

To test the validity and reliability of the results of the communication-instrument 
reliability

Guide

Flexibility

Recurrence

Information the questionnaire is also held under a large population of relevant experts and employees. This extensive quantitative test showed, in comparison to the results of the panel conferences, no new insights in the educational needs of the branches of industry.

The results of the pilot-projects fit close with each other and resulted in the TRANSMIT guide. This TRANSMIT guide is meant to inform all kinds of branches of industry, how to set up a plan to translate the results of a branch study to specific task profiles and skills profiles of jobs and/or occupations in this branch of industry. The guide also shows the way to match the resulted skills profile with the offered training profile to execute relevant actions to reduce the mismatch between required and offered skills. The guide is accompanied by a card to order a floppy disk to frame the communication-instrument for the required and offered skills profile of the selected jobs, occupations and type(s) of training.

The flexibility of the contents of the TRANSMIT instrument is very high, but the TRANSMIT procedures have to be followed very strictly to achieve relevant results.

For a remaining communication between the branch of industry and the educational system, it is important to repeat the TRANSMIT process regularly. For the same or other jobs and occupations in the branch of industry.

TRANSMIT generates strategic, evaluative and sectoral information about the required and offered skills of jobs and occupations. Both the demand and supply side on the labour market are involved in the collection of this information. The generated information is focused on (branch specific) economic, technological and organizational changes and innovations - trends and the resulting skills shortages in jobs or occupations. TRANSMIT informs mostly about qualitative discrepancies on the labour market. Next to already existing literature and statistics, the TRANSMIT interviews generate highly structured information, which can be used for a more or less quantitative (graphical) presentation. However one must take into account the often very low number of interviewed experts. It is likely that the results of the TRANSMIT traject only will be published for the participants. The generated information can bear a somewhat confidential character. A more public distribution of the results, however, should be stimulated, because the different branches of industry and suppliers of training then can learn from their experiences. 


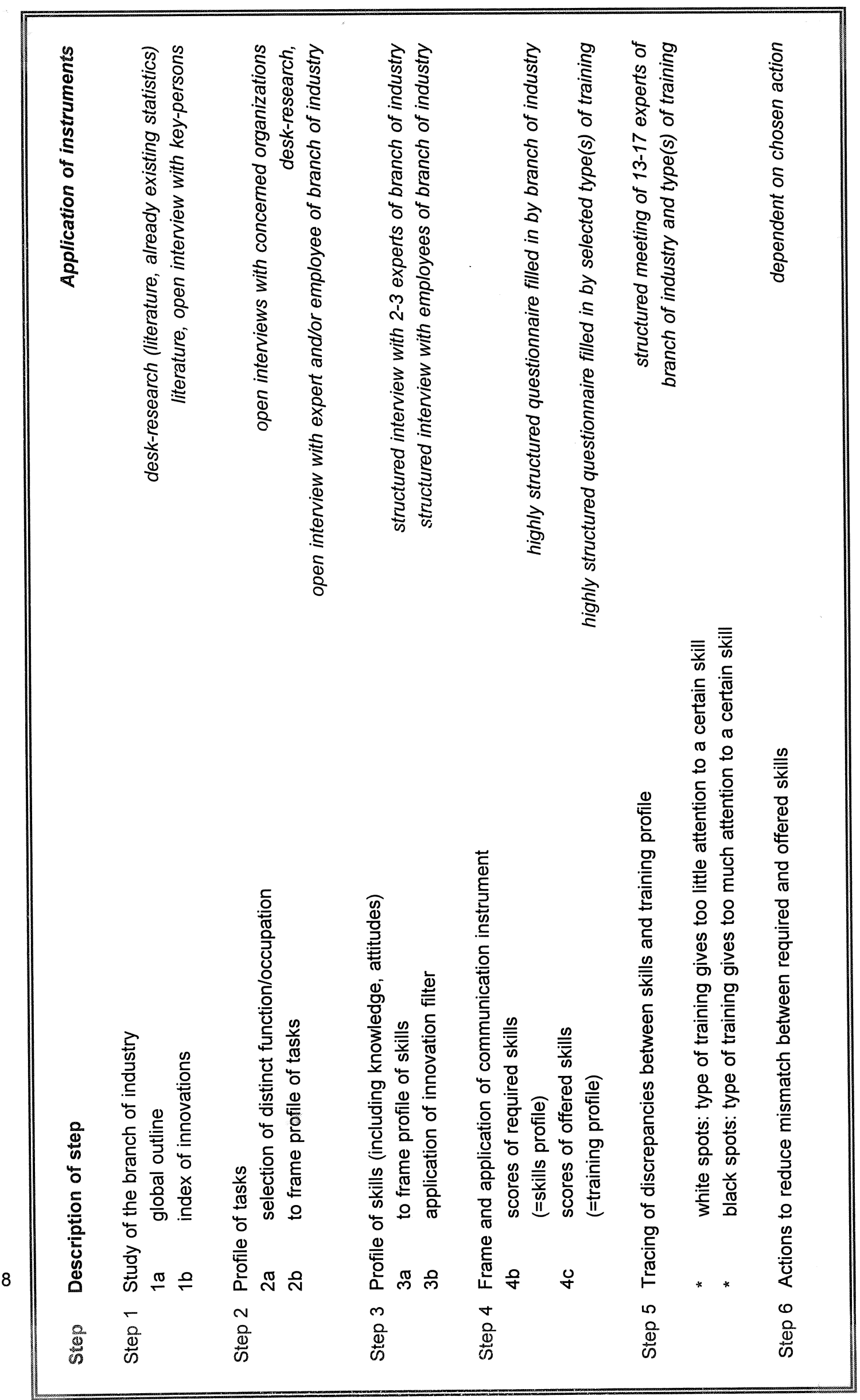


Specificity

Publications
The level of information is not useless detailled, but specific enough to derive concrete educational needs. For example, the skills profile indicates 'Knowledge of environmental laws', but the specific articles in the law aren't mentioned.

A\&O (1993), TRANSMIT Tippenboek, vertaling van branche-innovaties naar opleidingen, A\&O Adviescentrum Opleidingsvraagstukken, Bunnik, Ministerie van Economische Zaken, Den Haag, VUGA Uitgeverij B.V., Den Haag, the Netherlands (FI. 36, =; only available in Dutch).

Bilderbeek, R.H., P.E.B. Boekholt (1993), Van beroepspraktijkervaring naar beroepsonderwijs-programma's. Succesbevorderende en succesbelemmerende factoren in bedrijfstakgewijze vertaalprocessen, A\&O Adviescentrum Opleidingsvraagstukken, Bunnik, the Netherlands (FI. 29,75; only available in Dutch).

Vries, B. de, F. van Geest (1992), Brancheverkenningen in Nederland, A\&O Adviescentrum Opleidingsvraagstukken, Bunnik, the Netherlands ( $F I .15,=;$; only available in Dutch). 



\section{Mantel project}

Introduction

Involvement

Aim

Occupational practice

Use

Design

Phase 0

Phase 1

Phase 2

Phase 3

Phase 4
As a result of the advices of the 'Innovatie Commissie Participatie-onderwijs' (Innovation Committee Participation-education, ICP) and the 'Centraal Orgaan van de Landelijke Opleidingsorganen voor het leerlingwezen (central organ for national educational institutions for dual education, COLO), who pleaded for a more practical designed curriculum, the 'Mantel project' started in 1979.

COLO, Ministry of Education and Sciences, the Foundation for the Organized Educational System for Vocational Education (GSB), Pedagogical Centre Vocational Education Business Community (PCBB), the Ministry of Social Affairs and Employment, the Inspection for Dual Education and the National Organs for Dual Education.

The aim of 'Mantel project' (MP) is the development of an instrument for occupational analysis, in order to relatively fast and fully map the occupational practice.

The method can be placed in the context of curriculum development, in which the occupational practice determines de contents of the vocational education.

The MP-method can be used for the analysis of a single occupation up to the occupational practice in the whole branch or sector. The results can be used for the development of a complete range of educational supply, as well as for detecting overlap or gaps in educational supply.

The MP-method distinguishes three levels in the relation between education and labour:

- relation educational and labour system;

- relation education and labour market;

- relation education and occupational practice;

The MP-method distinguishes five phases:

The phase of preparation.

In phase 0 the research assignment is further elaborated towards the population that has to be examined and developing and testing the survey developed for phase 1.

Research to the (current) occupational practice.

In phase 1 a survey will be held among a sample of the occupational practitioners. The aimed output for this phase are the different job types, that represent the structure of qualification or functions within a branch of industry.

Enrichment research.

In phase 2 the job types are provided with additional information, that should 'enrich' the job types in such a way that they can be the base for the development of a curriculum.

Research towards future developments.

Phase 3 is used to gain insight in apparent and future developments within the branch of industry. Both new developments regarding new activities within functions as more general trends must be analyzed.

Construction of vocational education curriculum. 
Method

Survey

Respondents

Enrichment

Future developments

Danger

Translation steps
In phase 4 the information from the preceding phases is used to determine the vocational education curriculum.

The research regarding the occupational practice focuses at the tasks that have to performed (task inventories).

A survey is developed based on the task inventories. The task are classified on main tasks that contain coherent tasks.

For every task is asked for:

- whether the task is performed;

- the frequency of performance;

- the relative importance of the task;

Selection of respondents takes place by means of two dimensional sample matrix regarding the kind of organisation and the (expected) difference between job types.

The additional information in the enrichment phase has to give a decisive answer on aspects as:

- the nature of the task (cognitive, psychomotor, interactional);

- the degree of independence (in performing the task)

- the standards (minimal standards that the performance or the result has to come up to);

Designers of the job types provide the information; curriculum developers assess the information on completeness, unambiguousness and usefulness for the curriculum program.

In research to future developments a distinction can be made towards advanced tasks and future trends. The group performing advanced tasks or advanced functions have to be included in the sample determination of stage 0 . This group now is highlighted to determine the future job types, which should describe which and to what extent new activities will occur and the consequences of it for task that have to be performed in a function. For the future trends a group of experts has to be interviewed.

Interviewing experts inhabits the risk that these experts from their preoccupation with their own discipline tend to overemphasize the weight of certain developments.

In the continued research program a method has been developed for the construction of overall-programs based on the results of the occupational analysis. This method is based on twelve translation steps:

- Determine the structure of the occupational practice: determination and legitimation of job types.

- Determine the global contents of the job types: based on the percentage of task performances and the results of the future developments research the less relevant tasks are removed from the job types.

- Determine the qualification structure: make an outline of the types of education within the occupational field that indicates both the underlying job 
types as the relations between the various types of education.

- Establish an overall-program committee.

- Determine the global contents of the vocational part of the vocational education type: all tasks in the job type are judged on their relevance for the curriculum that has to be developed (educational relevance, percentage of task performance, average score on importance in survey and the results of the future developments research).

- Determine meaningful activity clusters: this phase contains two steps: 1 clustering of possible coherent themes around one theme;

2 final arrangement in meaningful clusters.

- Enrichment of the global types of vocational education (the vocational part): data regarding the enrichment categories are collected by means of a conference based procedure.

- Determine the necessary knowledge and skills: knowledge and skills elements are classified by means of a taxonomy by the overall program committee.

- Determine the place of education: for every task cluster has to be determined if in school or out of school education is the best way to provide the education.

- Determine the vocational part of the vocational education type.

- Determine the general part of the vocational education type: determine the final terms of the theoretic part and the general forming part of the educational type.

- Determine the overall program.

Delivery time

Information

Publications
Research to 6 cases show that the MP-method has a relatively long time path, ranging from 12 up to 25 months (1.1 up to 3.8 man-years). As a result of this time path may some of the results already be out of date.

The MP-method emphasizes on the characteristics and changes in the labour organisation, the spread of respondents over occupational experience and to a much smaller degree, the construction of occupations by type of education. The method tends to neglect out-flow data, career perspectives, selection criteria of employers, the place where skills must be taught, utilization of skills and nontechnical instrumental qualifications.

Brandsma, T.F. (1991), Beroepsprofiel- en leerplanontwikkeling: Een studie naar achtergroden, kenmerken en voor- en nadelen van methoden voor beroepsprofielontwikkeling, Enschede: Onerzoek Centrum Toegepaste Onderwijskunde, Universiteit Twente.

Pedagogisch Centrum Beroepsonderwijs Bedrijfsleven (1989), handleiding Totaalprogrammaontwikkeling, 's-Hertogenbosch.

Mantelproject (1983), Handleiding voor beroepenanalyse, 's-Hertogenbosch: Pedagogisch Centrum Beroepsonderwijs Bedrijfsleven.

Mantelproject (1983), Achtergronden van beroepenanalyse, 's-Hertogenbosch: 
Pedagogisch Centrum Beroepsonderwijs Bedrijfsleven.

Moerkamp, T. \& Ostenk, J.A.H.M. (1991), Van beroep naar opleiding: Inventarisatie van procedures voor het ontwikkelen van beroeps(opleidings)profielen, Utrecht: RVE Adviescentrum Volwasseneneducatie.

Westerhuis, A. (1987), Beroepenanalyse 1983 - 1987: Realisatie van het vervolgplan Mantelproject, 's-Hertogenbosch: pedagogisch centrum beroepsonderwijs Bedrijfsleven. 


\section{Curriculum conference}

Introduction

Generative Leitsystem

Criteria

Aim

Definition

Central theses
The curriculum conference has been introduced in the early 1980's by Frey, for preparing, taking and legitimating curriculum decisions. The curriculum conference is an extension of the 'Generative Leitsystem' of Frey and Aregger.

The 'Generative Leitsystem' forms the frame of reference in which not only curriculum research can be initiated and realised, but in which also the results can be interpreted.

The 'Generative Leitsystem' has to meet four criteria:

- It must be able to be changed at all times;

- It must be able to incorporate new research outcomes at any time;

- It must be able to lead to theses of different scientific character;

- It must be able to classify research activities.

The curriculum conference is the realization of the communicative legitimation process that leads, by means of free discussion and consensus, decision making, and is in the meantime a phase in the process of curriculum development and curriculum realisation. The conference is not meant to come to an elaborated curriculum. The elaboration is seen as the task for those who are going to implement the curriculum.

Within the curriculum theory the curriculum is not seen as a static product, but as a component in the process of developing and realizing the statement of the intention, principles and organization of a school.

The process can be subdivided in four constituent elements:

- Development of a general goals orientation (guidelines for the planning of forms of education regarding the respect for the development of one's personal abilities);

- Mutual consideration on the intended changes in the curriculum (to come to legitimation of the form of education).

- Creation of a relative distance (for the persons involved in the mutual consideration tis means creating distance towards the field of education in which they are involved);

- Reflection on the field of education, regarding the three preceding constituent elements.

The central thesis of the curriculum conference is:

- How should the general curriculum look like according to the conference participants?

- Who should get involved in the preparations for the future form of education during the continuation of the process of curriculum development and realisation, in which way should they get involved and which competencies, activities, realisation features and institutional conditions should be satisfied?

The curriculum conference contains three phases: 
Phase 1

Information document

Phase 2

Conference participants

Selection

The role of experts

The chairman

Conference design
Preparation (drawing up the information document, selection and invitation of participants and experts);

The information document is the scientific source. It has to describe the field of education from a historical perspective, the current situation and future developments. The historical perspective is emphasised in order to prevent the participants from approaching the problem in a subjective and non-historical manner. The document has to be composed by a group of experts and/or members of the organizing committee.

The actual conference;

The participants of the curriculum conference perform a dual task. On the one hand they are a source of information, while on the other hand they are the legitimation of the product.

Both the course of the process and the product are influenced by the personal characteristics and competence of the individual participants. To adjust for these influences three general criteria for the selection of participants must be used:

\section{- Distance-demand}

The participant has proved to be capable to systematicly consider and reflect his/her own field of work, as well as to individually explore the field of work in a broad context regarding education. Furthermore the participant has to have his considerations and opinions made known.

\section{- Expertise-demand}

The participant contributes his own expertise. This expertise has been developed in interaction with persons from outside the personal fields of work and at least partly related with education. Moreover, the participants must have the capabilities of incorporating opinions, based on the knowledge or opinions of others, in their own expertise.

- Demand of pedagogical intention

The participant must have been involved in realizing elementary educational aims.

Next to the conference participants, experts and the chairman are very important for the curriculum conference.

Experts do not actively participate in the conference. Their task is not only to support the participants as regards contents, when asked for by the participants but also to train participants in the behavioural rules of the conference and to guard the application of these rules during the conference.

The chairman has to lead the conference and look after the application of the behavioural rules, the progress of the process and the realisation of process and product goals.

The curriculum conference inhabits the following phases:

- Getting acquainted

- Development of general goals for the type of education for which the 
curriculum must be developed

- Training in the communication rules (rational reasoning and on the theme centred interaction):

* No prejudices: conference participants have to be open to opinions and arguments of other participants.

* Free of (implicit) compulsion: participants must feel free to express their own opinions and arguments.

* Free from persuasion: from the participants is expected to, only by means of arguments, change the other participants opinions.

* Clarification duty: participants are obliged to clarify the concepts used when their meaning is not clear.

* Foundation duty: participants are obliged to found their statements in such a way that other participants can accept them.

* Justification duty: participants are obliged to found and justify normative statements.

* Motivation: the participants are expected to be motivated to share arguments and opinions of other participants to come to consensus.

* Knowledge of the subject: participants should have at least basic knowledge on the subject to understand each other's opinions and arguments.

* Trans-subjectivity: the decisions that the participants take, they have to take in the knowledge that also others will be confronted with these decisions and also must be able to work with them.

\section{- Elementarisation}

Elementarisation implies that the conference participants by means of a foundated discussion valuate the information as described in the information document. It is an interaction between (more or less) objective knowledge of the educational field and the subjective knowledge of the participants.

* Discussing and clearing up indistinct passages and concepts in the information document.

* Discussing the information document to gain insight in the current relations and the structure of the field of education. Also possible future developments should get attention. In this phase experts may be consulted.

* Explanation of what the field of education means to the individual participants and what experiences they have regarding the field of education.

* Formulating changes or additions to the information document based on not only knowledge, experiences, expectation and emotions of participants, but also based on information from related disciplines.

\section{- Codification}

The phase of didactical reconstruction i.e. codification, combines the different sources of information from the elementarisation phase. The information is synthesized in an educational design, which can be used for further development and educational planning. The participants than formulate conclusion and elaborate these in legitimated curriculum products. 
Phase 3

Form of final product

Two different versions

Delivery time

Information

Publications
The final strokes and design of the product.

The information about the final strokes and design of the product are rather vague in the literature. The final product should be a general curriculum and decisions regarding the institutions and organisations in the field of education who should be involved in the further elaboration of the general curriculum.

The form of the final product should fulfil the following demands:

- The final product must have an open format, so as to make it possible to hand over the experiences and decisions from the curriculum conference in the final product, to persons not involved in the conference.

- The final product should not only show the codified results, but should also give information about the development of these codified results.

- The final product should incorporate the criteria for the use of the final product by interested parties.

In the Netherlands two different versions of the curriculum conference are developed. The first version has been developed by the Department of Curriculum Technology (CRC) of the Faculty of Applied Educational Research of the University of Twente. The second version has been developed by the Institute of Curriculum Development (SLO). There are some small differences between the various versions (see Brandsma, 1993).

Research to the delivery time showed for the five cases studies a range from 6 up to 27 months or 0.35 up to 3 man-years.

The curriculum method lays great emphasis on the characteristics and changes in the labour organisation. Also non-technical instrumental qualifications and the place where the skills should be taught are emphasized. However, the method tends to neglect data regarding to outflow, career perspectives, construction of occupations by type of education, selection criteria of employers, the spread of respondents over occupational experience and the utilization of skills.

Aregger, K \& Frey, K. (1972), Anlage von Bezugssystemen für den Curriculumprozess, ed. Aregger, K. \& Isenegger, U., Curriculumprozess: Beiträge zur Curriculumkonstruktion und -implemention, Freiburg: Universität Freiburg, Pädagogisches Institut.

Brake, J.J.M. te (1988), Het ontwikkelen en beproeven van instrumenten voor de analyse van processen van besluitvormingsprocessen van curriculumconferenties, Enschede: Univeriteit Twente.

Brandsma, T.F. (1993), Beroepsprofiel- en leerplanontwikkeling; de koninklijke weg als naïef traject?, Enschede: Universiteit Twente.

Frey, K. (1982), Curriculum-conference: An approach for curriculum development in groups, Kiel: Institute for Science Education.

Grönloh, H. (1984), De leerplanconferentie: Een werkmodel bij de constructie 
van een erkend beroeps- en opleidingsprofiel, Enschede, SLO, Instituut voor de Leerplanontwikkeling.

Malliou, K. (1990), Argumentation im curricularen Prozess: Eine fallstudie zu Anspruch und Qualität kommunikativer Handlungen der Curriculum-konferenz, Kiel: Institut für die Pedagogik der Naturwissenschaften (IPN).

Mulder, M. (1992), The curriculum conference: Evaluation of a tool for curriculum content justification, Enschede: Faculteit de Toegepaste Onderwijskunde, Universiteit Twente. 



\section{Information system on education and the labour market}

Introduction

Involvement

Aim

National

Design

Data suppliers

Labour Force Survey

Trends \&

Employment risks
Since the establishment of the Research Centre for Education and the Labour Market (ROA) in 1986, ROA is developing the Information System on Education and the Labour Market.

ROA developed this information system, which is already been operational for a number of years, on behalf of the Ministry of Education and Science, the Central Employment Board (CBA) and the National Career Guidance Information Centre (LDC). Nevertheless ROA is still working at a further development of this information system.

The aim of the Information System on Education and the Labour Market is to provide periodically data, trends and indicators on the current and future labour market situation for different occupations and types of education (and economic sectors). The position of the types of training and occupations is indicated by risk indicators and medium-term forecasts of changes in employment levels and replacement demand. For the different types of training the flow of schoolleavers onto the labour market is also estimated. On base of a match between the demand and supply side of the labour market, the future labour market perspective of school-leavers from different types of training is calculated.

The Information System on Education and the Labour Market is a national instrument to analyse mainly quantitative trends. The system provides information on the total Dutch labour market, broken down by 12 economic sectors, 93 occupations and 49 types of education. It is also possible to distinct from the information system the labour market information of one or more specific economic sectors, occupations, educational types, and regions. In such a case the information system becomes a sectoral or regional instrument.

Diagram 1 shows the design of the ROA Information System on Education and the Labour Market. In the upper part of the diagram the data suppliers of the information system are mentioned. The input of the information system is made up to a large extent of already existing external or internal data. The construction of the Information System is therefore mainly the consequence of an complex integration and a secondary analysis of these data.

One important basis are the data from the Labour Force Survey (Enquête Beroepsbevolking, EBB) of the Central Bureau of Statistics (CBS) on the numbers of working people analysed by economic sector, occupation, training, age, sex and working hours, and further data on the numbers of pupils and students in the educational system. These data are used for the estimation of developments on the labour market and educational system and for the estimation of employment risks, such as the sensitivity to cyclical fluctuations and the alternative employment possibilities, which are linked to the choice of a certain type of education or occupational class. These Labour Force Survey data are also necessary to estimate the models concerning the extension and replacement demand, on which the forecasts are based. 
Diagram 1

The status of ROA's information system on education and the labour market

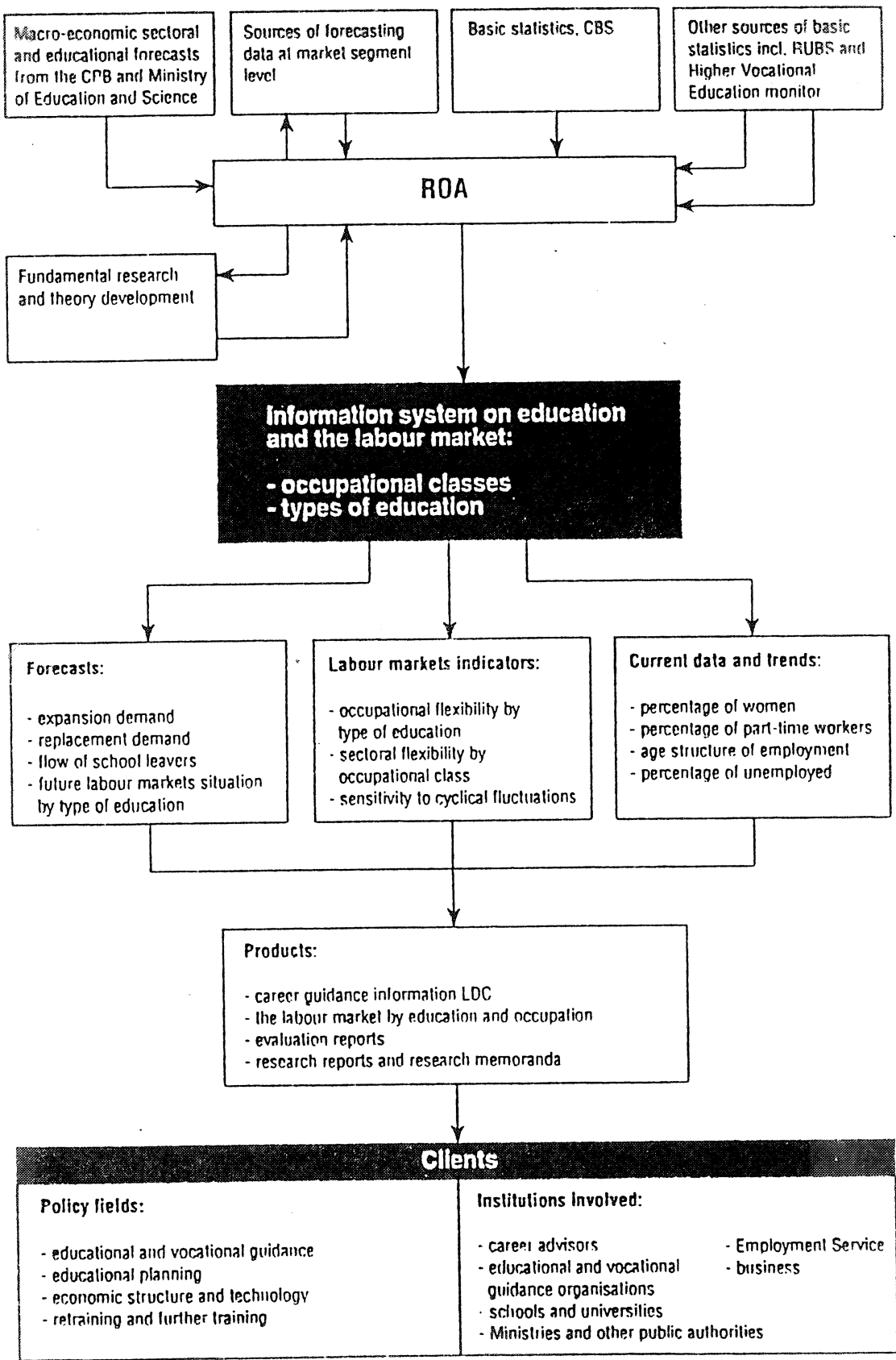


Student count

Destination surveys

Forecasts

Information

Transfer of knowledge
In addition to the CBS data files, ROA is pursuing other sources of statistical data to provide a more detailed picture of certain parts of the labour market or the educational system. ROA uses for example, in the educational sphere, the complete student count (Integrale Leerlingtelling) made by the Ministry of Education and Science. Furthermore ROA, in cooperation with other institutes, is active in presenting data on the labour market destination of secondary school-leavers (RUBS survey) and graduates from higher vocational education (HBO-Monitor). More information about these surveys is given in the next chapter. Although there is not yet a national instrument to survey the labour market destination of graduates of all universities in the Netherlands, some universities and faculties already question their graduates on this subject.

The medium-term forecasts of macro-economic changes and of employment levels in economic sectors of the Central Planning Bureau (CPB), are an important starting point for ROA's forecasts of changes in the labour market. Based on these forecasts, ROA predicts the consequences at occupational or educational level. In addition the forecasts of the outflow from education, made by the Ministry of Education and Science (Referentieramingen and HBOVerdeelraming) and by ROA itself, are used. Forecasts which give a better and more differentiated picture of certain segments of the labour market, such as particular forecasts of nurses, teachers clinical psychologists and research \& development staff, are also being sought.

The lower part of the diagram shows what information the system yields; its format, and which policy fields could benefit from the information. Three kinds of information are distinguished here: current data and trends, forecast data and indicators of the match between education and the labour market. The information mainly gives insight into possible quantitative discrepancies on the labour market. In comparison with other instruments to analyse skills shortages, the information system contains relatively global information.

The information is produced in the form of automated databases as well as public research reports, research memoranda, working papers and reprints of articles. Every other year the results of the Information System are published in a readily accessible report: The Labour Market by Education and Occupation. The statistical appendices of this report are updated annually. ROA also supplies biannually the labour market data for the public interactive information system "Studie Traject '93" for study and occupational choice for students of secondary education, who want to go to higher education. This system is available on a CD-ROM, and is commercially exploited by the LDC. The labour market information in Studie Traject '93 is combined with annually updated information on occupations and all types of training in tertiary education. A comparable CD-ROM will be exploited for students who want to choose for secondary vocational education. Analyses of the equilibrium of demand and supply in the labour market for specific economic sectors, occupations, types of educations, or regions (Provinces or Employment Exchange (RBA) regions) are also possible. 
Evaluation \&

Improvements

Extensions

Practical use for policy decisions

Publications

Traject
Furthermore ROA evaluates biannually the forecasts and the methodology used, and regularly improves and re-estimates the models for forecasting employment levels and replacement demand for occupational classes and types of education, and for the outflow from the educational system.

Steps have already been taken to the following extensions of the Information System on Education and the Labour Market:

- the addition of data on the labour market position of graduates from secondary and higher vocational education to the used statistical database;

- the addition of international labour market data, particularly for neighbouring countries and regions;

- a further desaggregation of the involved types of training upto 117 types;

- an extension of the description of the labour market perspectives of the types of training: not only a relative score on the match between demand and supply, but also insight into the consequences of these discrepancies (unemployment, lower wages, utilisation of skills below qualification).

One of the principles of the ROA Information System on Education and the Labour Market is, that the generated information is presented in such a form as to be of practical use in the policy decisions of public authorities, employment services, private enterprises, educational institutions and student counsellors. At present the information supplied is intended primarily for educational and vocational guidance and for economic structural, technology, labour and educational policy. However, the data offer a good starting point for planning curricula and educational capacities and can be useful for the planning of (further) training for workers and the unemployed, and for personnel planning in companies and institutions.

ROA (1993), De arbeidsmarkt naar opleiding en beroep tot 1998, (the labour market by education and occupation to 1998), Report \& Statistical Appendix, ROA-R-1993/10+10B, Researchcentrum voor Onderwijs en Arbeidsmarkt (ROA), Maastricht, the Netherlands (FI. 45,=; available in Dutch and English).

Borghans, L., P. van Eijs, A. de Grip (forthcoming), Evaluatie arbeidsmarktprognoses naar opleiding en beroep in 1992, (An Evaluation of Labour Market Forecasts by Type of Education and Occupation for 1992), Researchcentrum voor Onderwijs en Arbeidsmarkt (ROA), Maastricht, the Netherlands (available in Dutch and English).

Berendsen, H., A. de Grip, M.H. Wieling, E.J.T.A. Willems (1992), Regional Labour Market Forecasts by Education and Occupation in the Netherlands, ROA-RM-1992/5e, Researchcentrum voor Onderwijs en Arbeidsmarkt (ROA), Maastricht, the Netherlands (FI. 12,50; available in English).

LDC, Studie Traject '93, interactive CD-ROM, Landelijk Dienstverlenend Centrum voor Studie- en Beroepskeuze-voorlichting (LDC), Leeuwarden, the Netherlands (FI. 550, = per year; only available in Dutch). 


\section{Labour market scanners}

Introduction

Scanners

RL-Scanner

HBO-Monitor

RUBS
Educational policy of the government has developed in the late 80 s towards more autonomy for the institutions of education. This also means that these institutions are held responsible for assuring the quality of their training. In this respect several systems for measuring the quality of education and training have been developed, especially in higher education. The main form of self regulated assurance is the 'visitation committee', which is a form of 'peer review'. These committees visit the educational institutions every 3 or 4 year. Basis of the discussion held at the institutions are self-evaluations on curriculum, efficiency, drop-out rate, labour market entry of graduates, job outcomes etc.

One of the problems in using information on education and training output towards the labour market is that the data are often collected on an ad-hoc basis. This leads to differences in definitions, classifications and indicators. Therefore the information is often not comparable and cannot be used at a national level. However, since a few years three different labour market scanners have been developed which aim to give at a national level a representative picture of the entry on the labour market of graduates and school-leavers as well as output indicators at the level of the educational institution (the so-called 'Destination Surveys'). These - large-scale - destination surveys concern the outflow of both secondary and tertiary education.

The Research Centre for Education and the Labour Market of the University of Limburg (ROA, Maastricht) developed in 1989 a labour market scanner for universities, which exists of instruments to monitor regularly the developments on both the supply and demand side of the labour market. The design of this labour market scanner was the starting point for the scanner for graduates of

the University of Limburg (RL), the RL-Scanner and for the national monitoring of graduates of higher vocational education (HBO), the HBO-Monitor. Since 1994 two faculties of economics and business administration join the basic survey of the RL-Scanner. For the faculty of civil engineering ROA examined also the labour market careers of their graduates. In the next future ROA is willing to develop a national labour market scanner for graduates of all universities and faculties. The designs of the HBO-Monitor and RL-Scanner form the starting-point for this. Furthermore ROA coordinates the activities in the national project RUBS: Registration of the Outflow and Destination of Schoolleavers of general and vocational secondary education. Unfortunately, in all these instruments only the supply side of the labour market, i.c. the graduates and school-leavers, is involved. In 1990, however, ROA got the opportunity to develop a Labour Market Scanner for the Care and Welfare Sector, as part of the monitoring system for this sector, in which both sides of the labour market are included. By means of a panel study the developments in the occupational structure in the care and welfare sector were investigated. The study on the labour market position of graduates of the higher social-agogic education was linked to the HBO-Monitor. Below the projects RUBS, HBO-Monitor and RLScanner are further explained separately, after the explication of the common aim and the main principles and users of these labour market scanners. 
Aim

Principles

Scientific

responsibility

Comparable \& Flexible

External comparability

Topical

Time series

Accessibility \&

Privacy
The aim of these labour market scanners is to monitor periodically (annually) the quantitative and qualitative dimensions of the entry on the labour market of graduates and school-leavers. The fit between their training and professional practice is one of these (qualitative) dimensions. These surveys have to result in reliable and national representative data, which can be used for educational and labour market policy and further research, for example as input for the refinement of the Information System on Education and the Labour Market (see before). These destination surveys generate also output indicators for the participating educational institutes.

The design of the labour market scanners aims at a scientific process of the collection, handling, calculation and presentation of the data. The data have to be valid, reliable, consistent and representative for the total population.

For every type of education key-indicators are collected by means of a basic questionnaire. This core information is the same for every educational type. This makes a mutual comparison possible.

If additional or training specific information is desired, the basic questionnaire can be enlarged. This additional or specific information can also be compared with the basic information. The distinction between basic and additional information can also be applied at the products (reports, data sets etc.).

The comparability concerns also external data sources, e.g. the Labour Force Surveys. The definitions and classifications used in the labour market scanners fit in with the commonly used definitions and classifications of the Central Bureau of Statistics (CBS), which links these definitions and classifications to the standards of for example the International Labour Organization (ILO).

Due to the fast labour market developments it is necassary that the labour market position of graduates and school-leavers is monitored every year. Especially because graduates and school-leavers are the first to experience changes on the labour market. Furthermore it is important that the results of the labour market scanners are available in a short period of time.

After some years it will be possible to analyse time series of the data generated by these annually held destination surveys. Time series on labour market issues give insight in trends on labour market processes and form the starting-point of forecasting the future labour market perspectives for occupations and types of education.

ROA has made a rules and regulations code to control the process of the and the use of the data. The privacy of the respondents is also regulated and the calculations and reports are executed on an anonymous dataset. This code is based on the code of behaviour on personal registers of the Association of Research Institutes, of which ROA is a member. 
Information about the (starting) positions of school-leavers on the labour market is of great importance for the government, Employment Exchange and other employment agencies, employers' federations, trade unions, researchers, educational and vocational guidance organisations, career and vocational advisers, schools, colleges and universities, (coming) students and their parents. The information can be used for educational and vocational guidance, quality care systems and self-evaluation reports, adaption of curricula, (re)training programmes, educational planning, employment policy, and of course research in the field of education or the labour market. For ROA itself these data can be used to desaggregate the information of the Information System on Education and the Labour Market (see before).

Products

\section{RUBS}

Level

Funding

Project organisation

Methodology
At the one hand public reports for the different types of education at a national level are published, concerning descriptions, (multivariate) analyses and graphics/tables. On the other hand confidential reports at the level of the participating institutions are produced. These consist of standard tables and corresponding explanations. In this way, the management of the institutions of education can compare the institutions' own output with the output at the national level for several key-indicators.

General secondary education and lower and intermediate vocational education.

National funding from the National Career Guidance Information Centre (LDC), also on behalf of the Ministry of Education and Science, the Central Employment Board (CBA) and the Ministry of Agriculture, and the Joint Bureau of Advisors on Education and Career (GBOB).

Regional funding from Regional Employment Boards (RBA's), regional and local governments.

- The Research Centre for Education and the Labour Market of the University of Limburg (ROA, Maastricht) is charged with the national project management and carries out the scientific tasks in the project (research design, development of the instruments, analysis and national reports).

- Desan Marktonderzoek in Amsterdam coordinates the data collection, takes care of the processing of the data and produces the institute-reports.

- The Education and Employment Advice Offices (AOB's) take care of the guidance of participating schools and the regional implementation of the results.

- The schools participating in the sample are charged with distributing the questionnaires among their school-leavers. They can contract this out to Desan Marktonderzoek.

Crossectional survey, carried out annually, among a national representative sample of some 20,000 school-leavers (whether as drop-outs or with qualifications). The sample is stratified by type of education and region and is funded by national means. Regionally this sample may get extended by regional funding in order to get a regionally representative sample. The regional 
Research population

Start

Reports

HBO-MONITOR

Level

Funding

Project organisation

Methodology additions mount up to some 30,000 school-leavers, which brings the total sample on 50,000 (approximately $15 \%$ of the population). The sample is a cluster-sample, that is schools are selected in the sample and from these schools all school-leavers are selected for the sample. The survey is held approximately 9 months after leaving school. Information is obtained by a mail questionnaire.

Graduates and dropouts from secondary education, that is general secondary education (AVO), and junior vocational education (LBO) and senior vocational education (MBO).

The project has been carried out for several years in different regions by the Contact Centres for Education and Labour (nowadays: AOBs). In 1992 it has been extended to a nation-wide representative survey.

Wieling, M.H., P.J.E. van de Loo, R.K.W. van der Velden (1993), What has happened to school-leavers of the Secondary Technical Education? The outflow and destination of the graduate year 1990/1991, National Career Guidance Information Centre (LDC), Leeuwarden, Meppel.

Wieling, M.H., P.J.E. van de Loo, R.K.W. van der Velden (1993), What has happened to our school-leavers? The outflow and destination of the graduate year 1990/1991, National Career Guidance Information Centre (LDC), Leeuwarden/Meppel.

Smoorenburg, M.S.M. van, R.K.W. van der Velden, P.J.E. van de Loo, M.H. Wieling (1994), The destination of school-leavers, graduate year 1991/1992, National Career Guidance Information Centre (LDC), Leeuwarden, Meppel.

Tertiary education: higher vocational education.

National funding from the Council for Higher Vocational Education and the participating Institutes for Higher Vocational Education.

- The Research Centre for Education and the Labour Market (ROA) is charged with the project management and carries out the scientific tasks in the project (research design, development of the instruments, analysis and national reports).

- Desan Marktonderzoek in Amsterdam coordinates the data collection, takes care of the processing of the data and produces the institute-reports.

- Labour Market Research Bureau STOAS, Wageningen coordinates the integral participation of the Institutes of Higher Agriculture Education.

- The participating Institutes for Higher Vocational Education are charged with distributing the questionnaires among their graduates. They can contract this out to Desan Marktonderzoek.

Crossectional survey, carried out annually, among the graduates of the participating institutes. Participation is on a voluntary basis. It amounts to some 
Research population

Start

Reports

\section{RL-SCANNER}

Level

Funding

Project organisation
$60 \%$ of the total number of Institutes for Higher Vocational Education with some 16,000 graduates in 1991 up to 25,000 in 1993 . From the participating institutes all graduates are included in the sample.

The survey is held approximately 18 months after leaving education. Information is obtained by a mail questionnaire.

The participating institutes are offered the possibility to question graduates from other graduate years, to obtain information about other stages in the careers of these graduates. Colleges can also choose for a longitudinal design in which the already questioned group of graduates again is approached to update the information on their careers.

Graduates (not dropouts) from Higher Vocational Education. Since 1993 all sectors of Higher Vocational Education are involved. The first two years graduates from Higher Agriculture Education did not participate, although they were approached with a comparable instrument by a different organisation (STOAS, Wageningen).

The project has started in 1991 and has been carried out for three years now.

Loo, P.J.E. van de Loo, G.W.M. Ramaekers, R.K.W. van der Velden (1992), The labour market position of graduates of Higher Vocational Education, HBOMonitor 1991, national reports for every sector in higher vocational education and summary, Higher Vocational Educational Council, The Hague.

Loo, P.J.E. van de Loo, R.K.W. van der Velden, M.H. Wieling, J.M.J.A. Pisters, M.C. Gimbrère (1993), The labour market position of graduates of Higher Vocational Education, HBO Monitor 1992, national report, statistical supplement and summary, Higher Vocational Education Council, The Hague.

Loo, P.J.E. van de Loo, R.K.W. van der Velden, J.M.J.A. Pisters, R.J.P. Dekker (1994), The labour market position of graduates of Higher Vocational Education, HBO Monitor 1993, national report and statistical supplement, Higher Vocational Education Council, The Hague.

Tertiary education: academic education.

Funding by the Board of Governors of the University of Limburg. The development of the instruments was funded by the Ministry of Education and Science.

- The Research Centre for Education and the Labour Market (ROA) is charged with the project management and carries out the scientific tasks in the project (research design, development of the instruments, analysis and reports).

- The Office of Student Affairs of the University of Limburg handles the administrative aspects of the data collection. 
Methodology

Research population

Longitudinal survey among graduates of the University of Limburg. The information is obtained annually through two mail questionaires. The first is the basic questionnaire, used to survey all of the previous year's students approximately one year after their graduation. The second is the annual questionnaire, which is sent each year as a follow-up to the questionnaire. With this form the respondent can report changes in his or her labour market position over the past year, for instance a change of jobs.

The scanner is now fully implemented at the University of Limburg. All graduates who left this university since 1986 are included in the sample. In 1992 this amounted to some 2,500 graduates. As of 1992, attempts have been made to extend this monitoring system to other universities. Preliminary talks have been taken place with representatives of different faculties. A first addition has been made at the University of Delft, which has asked ROA to examine the labour market careers of graduates from the faculty of civil engineering. Since 1994 the faculties of economics and business administration in Rotterdam and Tilburg join the basic questionnaire of the RL-Scanner.

The project has started in 1989.

Reports

Dam, J.W. van, J.A.M. Heijke, G.W.M. Ramaekers (1989), Design of a labour market scanner for academic graduates, ROA-R-1989/3, Research Centre on the Education and the Labour Market (ROA), Maastricht.

G.W.M. Ramaekers, J.A.M. Heijke (1991), Labour market scanner of the University of Limburg, Graduates 1986-1989, ROA-R-1991/6, Research Centre on the Education and the Labour Market (ROA), Maastricht.

G.W.M. Ramaekers, J.A.M. Heijke (1993), labour market scanner of the University of Limburg, base-line measurements for the class of '90, ROA-R1993/1, Research Centre on the Education and the Labour Market (ROA), Maastricht.

G.W.M. Ramaekers, J.A.M. Heijke (1993), Labour market scanner of the University of Limburg, base-line measurements for the class of '91, ROA-R1993/13, Research Centre on the Education and the Labour Market (ROA), Maastricht.

G.W.M. Ramaekers, R.J.P. Dekker (1993), The labour market position and match between education and work of civil-engineers, ROA-R-1993/3, Research Centre on the Education and the Labour Market (ROA), Maastricht. 